\title{
microRNAs in viral acute respiratory infections: immune regulation, biomarkers, therapy, and vaccines
}

\author{
Stephen A. Leon-Icaza ${ }^{1,2}$, Mingtao Zeng ${ }^{2^{*}}$ and Adrian G. Rosas-Taraco ${ }^{1 *}$
}

\begin{abstract}
MicroRNAs (miRNAs) are single-stranded RNAs of 17-24 nt. These molecules regulate gene expression at the posttranscriptional level and are differentially expressed in viral acute respiratory infections (ARIs), which are responsible for high morbidity and mortality around the world. In recent years, miRNAs have been studied in order to discover anti-viral ARI drug targets as well as biomarkers for diagnosis, severity, and prognosis. This review presents an analysis of the regulatory response to viral ARIs of miRNAs, including their participation in the innate immune response, their utility as biomarkers, and their potential for future therapies and vaccine development.
\end{abstract}

Keywords: miRNA, Viral ARI, Rhinovirus, Influenza virus, hMPV, Coronavirus, RSV

\section{Introduction}

miRNAs are small molecules (17-24 nt) of non-coding, single-stranded RNA that inhibit the translation of mature messenger RNAs (mRNAs) [1]. There are more than 1881 miRNA precursor sequences in the human genome, allowing the generation of 2588 mature miRNAs according to miRBase 21.0 [2]. These molecules regulate around $60 \%$ of gene expression, they are present in a great number of biological processes, and their potential role as biomarkers in diagnosis and treatment is being explored [3]. Among the biological functions of miRNAs are maintenance of the epithelial cell barrier in the respiratory tract and regulation of anti-viral host defense [4]. Viral acute respiratory infections (ARIs) are the most common cause of acute respiratory symptoms (e.g., flu and bronchitis), and many of these infections have been linked to the exacerbation of symptoms in chronic respiratory diseases such as asthma [5].

The immune response against respiratory viruses, such as human rhinovirus (hRV), influenza virus (IV), human metapneumovirus (hMPV), human coronavirus (HcoV), and respiratory syncytial virus (RSV), is associated with

\footnotetext{
* Correspondence: mt.zeng@ttuhsc.edu; adrian.rosastr@uanl.edu.mx ${ }^{2}$ Center of Emphasis in Infectious Diseases, Department of Biomedical Sciences, Paul L. Foster School of Medicine, Texas Tech University Health Sciences Center El Paso, 5001 El Paso Drive, El Paso, TX 79905-2827, USA 'Department of Immunology, Faculty of Medicine, Universidad Autónoma de Nuevo León, Monterrey, NL, Mexico
}

altered expression of several miRNAs, and changes in the expression profile of the miRNAs in epithelial cells may contribute to the pathogenesis of acute as well as chronic respiratory diseases [4]. This review will analyze the biogenesis of miRNAs and their role in the regulation of viral ARIs.

\section{Biogenesis of miRNAs}

The biogenesis of miRNAs involves a series of complex steps that are encoded in intergenic regions, introns, and exons of the genome [6]. First, the pri-miRNA which is nearly identical to mRNAs but lacks the translation start codon (AUG) is transcribed in the nucleus by RNA polymerase II. Folding into a characteristic stem-loop structure [7], the pri-miRNA binds to the double-stranded RNA-binding domain (dsRBD) of the protein known as the DiGeorge syndrome critical region of gene 8 (DGCR8) and is then cleaved by the ribonuclease III Drosha (also known as RNASEN), which releases an intermediate stemloop structure of 60-70 nt known as the pre-miRNA. After cleavage, the pre-miRNA retains a phosphate at the $5^{\prime}$ cap and two nucleotides that protrude at the 3' cap. Exportin5 and RanGTP are then involved in pre-miRNA transportation to the cytoplasm [8]. Finally, the pre-miRNA in the cytoplasm is cleaved by the Dicer ribonuclease, which mainly recognizes the $5^{\prime}$ phosphate, generateing a doublestranded RNA (dsRNA) of approximately $22 \mathrm{nt}$ (known as 
the mature miRNA). This molecule is then uncoiled by a helicase, producing two mature, single-stranded miRNAs that are recognized by the Argonaute protein 2 (Ago 2), which is an essential component in the RNA-induced silencing complex (RISC) [9]. The mature miRNA assembled onto RISC can bind by complementarity to the untranslated $5^{\prime}$ or $3^{\prime}$ regions of their target mRNAs, which induces the degradation or translational repression of the mRNA [10].

\section{The role of miRNAs in the innate anti-viral response}

The host innate immune response is the first line of defense against all pathogens. A large variety of cells, such as epithelial cells [11], dendritic cells, granulocytes, monocytes, macrophages, and natural killer cells, play an important role in the immune response [12, 13]. Some miRNAs are produced during viral infection, modulating the function of all the previously mentioned cells.

Viral genetic material triggers activation of the host innate immune responses, and this material is recognized by several pattern-recognition receptors (PRRs), such as Nod-like receptors (NLRs), RIG-like receptors (RLRs), and, most importantly, Toll-like receptors (TLRs, Fig. 1) $[14,15]$. The interaction of genetic material with each of these receptors depends on whether the material is DNA or RNA and whether the RNA is single stranded or double stranded [16]. It is well known that respiratory viruses mainly interact with RLRs (such as RIG-I and MDA5 at the cytoplasmic level) [17] and with TLRs (such as TLR3, TLR7, TLR8, and TLR9 at the endosomic level as well as TLR2 and TLR4 at the surface of the cell membrane) $[18,19]$, which culminate in two signaling pathways. The first triggers activation of the NF- $\mathrm{kB}$ transcription factor, which initiates the transcription of pro-inflammatory cytokines, while the second is linked to activation of interferon regulatory factors (IRFs), which promote type I and III interferon gene expression (Fig. 1) [20], and miRNAs modulate both of these pathways (Table 1).

Reports have demonstrated that miR-136 interacts at the post-translational level with RIG-I to increase proinflammatory cytokine production [21]. miRNAs, such as let-7, may also act directly on the mRNA of a pro-inflammatory cytokine, such as IL6, to prevent its translation [22]. More recently, it has been reported that some miRNAs act on protein-coding mRNAs in signaling pathways such as IRAK1, which is a target of miR-146a (avoiding the activation of NF-kB), or IKKe (avoiding the activation of IRFs) [23]. Type I interferons are also targets of miRNAs [24], which may result in loss of the antiviral state (for example, miR-466i acts on IFN $\alpha$, and let-7b acts on IFN $\beta$ ) [25].

The IFN pathways not only favor the anti-viral state of cells but also trigger the overexpression of certain miRNAs

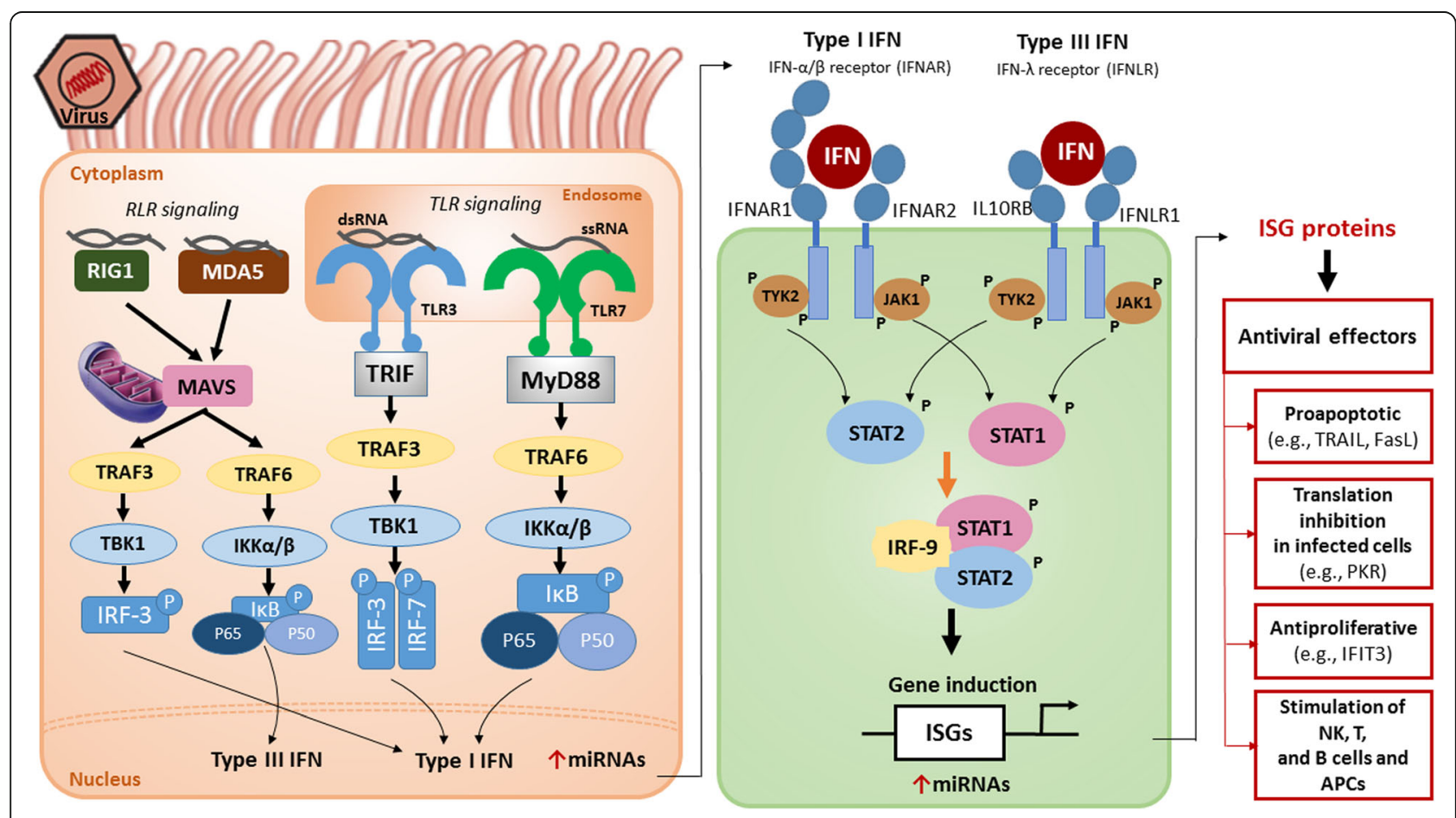

Fig. 1 The antiviral innate immune response. Left. The NF-KB pathway. Right. The IFN pathway 
Table 1 The miRNAs involved in viral acute respiratory infections (ARIs), their pathways, and the targets that they regulate $[2,83]$

\begin{tabular}{lll}
\hline Virus & miRNAs & Pathways and targets \\
\hline RV & miR-23b & Pathways: Cancer, Inflammation \\
& Targets: SPRY2 \\
& miR-128 & Pathways: Apoptosis, Cancer, Inflammation \\
& Targets: BMI1, BAX \\
& Pathways: NFKB, IRFs, Inflammation Mediators, \\
& Macrophage Inflammatory Response, Vascular \\
& Inflammation, Interleukins, TLRs pathways \\
& Targets: TNF, TAK1, IKK , SOCS1, RIPK1, IRAK3, \\
& IKBKE, IRF8, SMAD5
\end{tabular}

RSV let-7b

Pathways: Innate immune response, Cancer Targets: CASP3, SMAD2, SMAD4, TGFBR1, IL10, STAT3, TLR4

let-7d Pathways: IL6 / STAT3 Signaling

Targets: CASP3, SMAD2, SMAD4, TGFBR1, IL10, STAT3, TLR4

let-7i Pathways: Cancer, Innate immune response Targets: CASP3, SMAD2, SMAD4, TGFBR1, IL10, STAT3, TLR4. miR-24 Pathways: Apoptosis, Cell proliferation

Targets: E2F2, Myc, INK4a, CASP9

miR-26b Pathways: Inflammatory Response (IL-1), Pro-apoptotic, Cancer

Targets: SMAD1, SMAD4, PTEN, TAF12

miR-27a Pathways: Pro-apoptotic, Cancer, Wnt signalling pathway

Targets: IL10, SOCS6

miR-27b Pathways: Cancer, Innate immune response Targets: IL10, SOCS6, EGFR

miR-29c Pathways: Apoptosis, Wnt signalling pathway Targets: IL12B, CD276

miR-30b Pathways: Apoptosis, Inflammation, Cancer Targets: TP53

miR-31 Pathways: Pro-apoptotic, Cancer (tumour suppressor miRNA)

Targets: TIAM1, p53

miR-34b Pathways: Tumor suppressor, p53 pathway Targets: TP53, SIRT1

miR-34c Pathways: Apoptosis, Cancer, Inflammation, p53 pathway

Targets: TP53, SIRT1

miR-125a Pathways: Apoptosis, Cancer, Inflammatory Responses

Targets: MTOR, SMAD2, SMAD4, TNF, AGO2, IL6R, MYD88, TGFBR1, TP53

miR-125b Pathways: Apoptosis, Cancer, Regulate TNFa Targets: TNF, IL6R, AGO2, MYD88

miR-198 Pathways: Cancer, Cell proliferation Targets: ROCK1, SHMT1

miR-203a Pathways: Inflammation Mediators, Apoptosis, Cancer,

Targets: BCL2L2, p63, SOCS3, AP-1

miR-429 Pathways: Cell cycle, Insulin signaling Targets: STAT4, TGFB2, TGFBR1

miR-520a-5p Pathways: Innate immune response Targets: RELA, TGFBR2
Table 1 The miRNAs involved in viral acute respiratory infections (ARIs), their pathways, and the targets that they regulate $[2,83]$ (Continued)

\begin{tabular}{|c|c|c|}
\hline Virus & miRNAs & Pathways and targets \\
\hline \multirow[t]{4}{*}{ hMPV } & let-7f & $\begin{array}{l}\text { Pathways: Cancer, Innate immune response } \\
\text { Targets: CASP3, SMAD2, SMAD4, TGFBR1, IL10, } \\
\text { STAT3, TLR4 }\end{array}$ \\
\hline & miR-16 & $\begin{array}{l}\text { Pathways: Apoptosis, Cancer, Inflammation } \\
\text { Targets: MAPK3, MCL1, MYB }\end{array}$ \\
\hline & miR-30a & $\begin{array}{l}\text { Pathways: Apoptosis, Inflammation, Cancer } \\
\text { Targets: TP53, UGT8 }\end{array}$ \\
\hline & miR-192 & $\begin{array}{l}\text { Pathways: Apoptosis, Cancer } \\
\text { Targets: CD67, TYMS }\end{array}$ \\
\hline \multirow[t]{5}{*}{ IV } & let-7c & $\begin{array}{l}\text { Pathways: IL6 / STAT3 Signaling, Apoptosis, } \\
\text { Cancer } \\
\text { Targets: CASP3, SMAD2, SMAD4, TGFBR1, } \\
\text { IL10, STAT3, TLR4 }\end{array}$ \\
\hline & miR-17-3p & $\begin{array}{l}\text { Pathways: Cancer, apoptosis } \\
\text { Targets: CASP7, ATM, MAPK9 }\end{array}$ \\
\hline & miR-221 & $\begin{array}{l}\text { Pathways: Pro-apoptotic, Cell migration, } \\
\text { Proliferation, Oncogenic } \\
\text { Targets: CD117, KIT, STAT5A }\end{array}$ \\
\hline & miR-323 & $\begin{array}{l}\text { Pathways: Apoptosis, Proliferation } \\
\text { Targets: KIT, STAT3 }\end{array}$ \\
\hline & miR-491 & $\begin{array}{l}\text { Pathways: Apoptosis, Cell viability } \\
\text { Targets: BCL2L1 }\end{array}$ \\
\hline \multirow[t]{4}{*}{$\mathrm{HcoV}$} & miR-9 & $\begin{array}{l}\text { Pathways: Apoptosis, Cancer, Innate immune } \\
\text { response, NFKß } \\
\text { Targets: NFKB1, JAK1, JAK2, JAK3, PRDM1 }\end{array}$ \\
\hline & miR-98 & $\begin{array}{l}\text { Pathways: Anti-apoptotic, Cancer, Cytokines, } \\
\text { Inflammation } \\
\text { Targets: CASP3, IL10, KRAS, MYC, Ras, SMAD2, } \\
\text { SMAD4, STAT3, TGFBR1, TLR4 }\end{array}$ \\
\hline & miR-214 & $\begin{array}{l}\text { Pathways: Apoptosis, Cancer, Autoimmune } \\
\text { Disorders } \\
\text { Targets: AP-2, MAPK8 }\end{array}$ \\
\hline & miR-223 & $\begin{array}{l}\text { Pathways: Interferons \& Receptors, Interleukins } \\
\text { Targets: E2F1, IGF1R }\end{array}$ \\
\hline
\end{tabular}

that inhibit the NF- $\mathrm{kB}$ and IRF pathways. miR-155 is an example of an miRNA with these effects, as it has as targets TAK1 (inhibiting the NF-kB pathway) and IKKe (inhibiting the IRF pathway) [26].

\section{Expression of miRNAs during respiratory infections \\ Rhinovirus (RV)}

Rhinovirus is the main cause of upper respiratory tract infections in children and adults, and it predominantly infects the epithelial cells of the respiratory tract [27]. Rhinoviruses are single-stranded RNA viruses with icosahedral capsids and belong to the Picornaviridae family $[28,29]$. In the viral replication step, a dsRNA is generated that is recognized by TLR3 and RIGI [30, 31].

Bioinformatic software has been useful in predicting in silico whether certain miRNAs have viral mRNAs as targets, for which the response may be in favor or against the virus 
[32]. The miR-128 and miR-155 miRNAs were identified as possible regulators of the innate immune response against RV-1B [33], since they have as targets the genetic material from RV. A report demonstrated that gene silencing of these miRNAs increases RV replication by 50\% [34].

miR-23b is involved in the immune response against $\mathrm{RV}$, as it downregulates LPR5 and VLDLR transmembrane receptor expression [4]. These receptors are used by at least 12 RV types (RV1A, RV1B, RV2, RV44, RV47, RV49, RV23, RV25, RV29, RV30, RV31, and RV62) to infect cells [35].

\section{Respiratory syncytial virus (RSV)}

RSV contains a single strand of negative polarity [36, 37] that codes for 11 proteins (NS1, NS2, N, P, M, SH, G, F, M2-1, M2-2, and L) and belongs to the Paramyxoviridae family [38]. It is a common human pathogen that causes symptoms similar to those found in the common cold in adults and children. It generally affects the lower respiratory tract and is the respiratory virus most frequently isolated from children hospitalized for bronchitis. Primary infection usually causes an acute illness, while subsequent infections induce episodes of obstructive bronchitis [39-41].

RSV downregulates miR-221 expression in human bronchial epithelial cell culture, while miR-30b and let-7i expression increase after $48 \mathrm{~h}$ of infection. Overexpression of miR-30b and let-7i was observed in normal human bronchial epithelial cell line cultures infected with an RSV that lacks NS1 and NS2 proteins, and these proteins therefore play an antagonistic role to let-7i and miR-30b, causing inhibition of the production of type I IFN. Among the miRNAs with deregulation in the levels of expression during an RSV-A2 infection are miR-27a, miR-221, miR-339-5p, miR-453, miR-574, and miR-744, and all of these were overexpressed except for the last, which was underexpressed [42].

In a case-control study, the RSV-infected patients showed low levels of expression of miR-34b, miR-34c, miR-125b, miR-29c, miR-125a, miR-429, and miR-27b compared with control; meanwhile, miR-155, miR-31, miR-203a, miR-16, and let-7d were overexpressed. Patients were divided into three groups (severe, moderate, and mild, according to the severity of the illness), and in the mild group the miR-125a and miR-429 levels were found to be downregulated [43].

Studies have determined that RSV induces miRNA expression in at least two different ways. The first, in human monocyte-derived dendritic cells (MDDCs) and human bronchial epithelial cells, the induction of let-7b and let-7i, respectively, depends on IFN- $\beta$ [44]. Second, in human bronchial epithelial cells, miR-30b is induced independently of IFN but dependently on NF- $\mathrm{kB}$. Finally, RSV downregulates miR-221 expression in human bronchial epithelial cells [44].
It has been demonstrated that RSV infection in A549 cells deregulates miRNA expression, including for let-7f, miR-337-3p, miR-520a-5p, miR-24, miR-26b, miR-198, and miR-595 [45]. All these miRNAs have similar targets, including cell cycle genes (CCND1, DYRK2, and ELF4), a chemokine gene (CCL7), and the suppressor of cytokine signaling 3 gene (SOCS3). Moreover, a G protein of RSV increases the expression of let-7f, which acts against CCND1 and DYRK2, allowing cell cycle arrest in G1, favoring viral replication. The miRNA let-7 is an important key to the induction of host genes during viral infection [45].

\section{Human metapneumovirus (hMPV)}

hMPV is an important and recently discovered member of the Paramyxoviridae family [46], which also includes RSV and human parainfluenza virus [47]. The genome of hMPV lacks the non-structural genes NS1 and NS2 and includes eight open reading frames: $3{ }^{\prime}-\mathrm{N}-\mathrm{P}-\mathrm{M}-\mathrm{F}-\mathrm{M} 2-\mathrm{SH}-\mathrm{G}-$ L-5' [48]. Many clinical studies have shown that hMPV causes lower respiratory tract infections in pediatric patients [49-51].

It has been reported that hMPV induces changes in the miRNA expression profile (including for let-7f, miR4552, miR-30a, miR-16, miR-374a*, and miR-192) in the epithelial cells of the respiratory tract. In A549 cells, hMPV regulated the expression of 174 miRNAs over a period of $15 \mathrm{~h}$. One of the most important miRNAs overexpressed was let-7f, which has, as a possible target, the RNA polymerase of hMPV, and thus let-7f can control viral replication [52]. More studies designed to define the role of miRNAs during in vitro and in vivo hMPV infection are needed.

\section{Influenza virus (IV)}

Influenza is caused by a single-stranded RNA virus belonging to the Orthomyxoviridae family [53], and there are three types of influenza virus (IV): A, B, and C. Type A (influenza A) viruses are subclassified depending on the two proteins present on their surface, hemagglutinin and neuraminidase ( $\mathrm{H}$ and $\mathrm{N}$, respectively) [54]. There are 16 different types of hemagglutinin and 9 types of neuraminidase currently known $[55,56]$. The subtypes of IV with the currently highest circulation in America are influenza A (H1N1 or H3N2) and influenza B [57].

Influenza is an acute and contagious viral respiratory disease, and its characteristic manifestations are: fever, cephalea, myalgia, coryza, sore throat, and coughing. IV has a preference for the upper respiratory tract, but in severe cases it may affect the lower respiratory tract (lungs and bronchioles) [58].

The expression of miRNAs may be altered during an IV infection. miRNAs such as miR-323, miR-491, and miR-654 inhibit influenza A H1N1 replication, and these downregulate viral gene expression in infected cells [59]. 
An example of this mechanism is the degradation of the PB1 mRNA (involved in viral replication) of influenza A virus by host miR-323, miR-491, and miR-654 [60]. The inhibition of expression of the M1 protein of the type A IV is regulated by let-7c in A549 cells [60, 61]. Low expression of miR-17-3p and miR-221 was found in human alveolar basal epithelial cells during IV infection [62].

\section{Coronavirus (HcoV)}

Coronaviruses are wrapped in a coat of single-stranded RNA and positive polarity [63, 64]. They have been identified as the most frequent cause of respiratory tract infections [65], ranging from the common cold to severe acute respiratory syndrome (SARS) [66].

Coronaviruses are the causal agent of the common cold, which has a low mortality rate, because the host has a perfect mechanism for resolution of the infection in most cases [67]. This mechanism is depends critically on the OC43 protein of the coronavirus nucleocapsid [68]. Cells affected by the coronavirus activate signaling cascades, resulting in an increase in NFKB1 and miR-9 expression. NFKB1 mRNA is the target of miR-9, and this leads to the loss of translation of NF-kB; however, this outcome is avoided by the action of OC43, which binds to miR-9, allowing NF- $\mathrm{kB}$ translation, pro-inflammatory cytokine production, and type I interferon production, which are necessary to resolve the infection [69].

SARS, caused by SARS-HcoV, is an acute infectious disease with a significant mortality rate. Common clinical features associated with SARS are pulmonary fibrosis and pulmonary insufficiency [70]. Bronchoalveolar stem cells (BASCs) are the main cells infected by SARS-HcoV [71], which induces overexpression of miR-574-5p and miR214 . Some proteins of the viral nucleocapsid downregulate miR-223 and miR-98 expression in BASCs, which controls several stages of their differentiation as well as pro-inflammatory cytokine production [72].

\section{New therapies focus on miRNAs and their utility in vaccines}

In this review, we have discussed how miRNA expression is altered during viral ARIs, and these miRNAs are potentially useful as biomarkers and drug targets [73]. Currently, no drug exists that increases the levels of, or inhibits, any miRNAs in viral ARIs; however, there has been some progress on other diseases. The first inhibitory drug for a specific miRNA (miR-122) was created in 2010 and, as of this writing, is in phase II trials for hepatitis $C$ treatment [74, 75]. The first synthetic miRNA, miR-34 (MRX34), was developed in 2013 for the treatment of advanced hepatocellular carcinoma [76].

In more recent research, synthetic miRNAs have been generated that are carried by liposomes and transfected into the mononuclear cells of peripheral blood. These protocols increase certain pro-inflammatory cytokines, such as TNF- $\alpha$, favoring the innate immune response [77]. The most recent application of these miRNAs has been the creation of new vaccines with attenuated viruses that are loaded with an expression cassette encoding a synthetic miRNA that targets structural proteins of the virus. The PR8-amiR-93NP virus was generated by inserting an expression cassette for miR-93 between viral genes encoding non-structural proteins in an attenuated IV, and this miRNA specifically targets the nucleoproteins of the IV. This vaccine, administered intranasally, conferred immunity against several heterologous viral strains [78]. Plants also produce miRNAs that regulate virus replication. An example is MIR2911 in honeysuckle, which inhibits the expression of the PB2 and NS1 proteins of the influenza A viruses $\mathrm{H} 1 \mathrm{~N} 1, \mathrm{H} 5 \mathrm{~N} 1$ and H7N9 [79].

The main challenge in the development of miRNAbased therapies is the absence of an in vivo delivery method. Currently, the most common and effective method for the delivery of small RNAs (principally siRNAs) in the respiratory tract is their aerosolization with a microsprayer $[80,81]$. This approach is an area of opportunity to develop miRNA delivery for possible use in these respiratory infections [82].

\section{Concluding remarks}

miRNAs play a crucial role in the regulation of (in favor of or against) the innate immune response in viral ARIs. This regulation clearly differs according to the causal viral agent, and it is therefore important to explore the utility of miRNAs as biomarkers and for developing treatments and vaccines.

\section{Abbreviations}

Ago 2: Argonaute protein 2; ARIs: Acute respiratory infections;

BASCs: Bronchoalveolar stem cells; DGCR8: DiGeorge syndrome critical region of gene 8; dsRBD: Double-stranded RNA-binding domain; dsRNA: Double-stranded RNA; HcoV: Human coronavirus; hMPV: Human metapneumovirus; hRV: Human rinovirus; IRFs: Interferon regulatory factors; IV: Influenza virus;

MDDCs: Monocyte-derived dendritic cells; miRNAs: MicroRNAs; mRNAs: Mature messenger RNAs; NLRs: Nod-like receptors; PRRs: Pattern-recognition receptors; RISC: RNA-induced silencing complex; RLRs: RIG-like receptors; RNASEN/ Drosha: Ribonuclease III Drosha; RSV: Respiratory syncytial virus:

SARS: Severe acute respiratory syndrome; siRNA: Small interfering RNA; SOCS3: Cytokine signaling 3 gene

\section{Acknowledgements}

The authors thank Montserrat Rangel for help in generating the schematic diagram.

\section{Funding}

Consejo Nacional de Ciencia y Tecnología (CONACYT SALUD project number 2013-01-281871), and a scholarship to SLI. MZ is funded by US Public Service research grant Al118228 from the National Institute of Allergy and Infectious Diseases.

Availability of data and materials Not applicable. 


\section{Authors' contributions}

All authors wrote, read, and approved the final manuscript.

\section{Ethics approval and consent to participate}

Not applicable.

\section{Consent for publication}

Not applicable.

\section{Competing interests}

The authors declare that they have no competing interests.

\section{Publisher's Note}

Springer Nature remains neutral with regard to jurisdictional claims in published maps and institutional affiliations.

\section{Received: 10 May 2017 Accepted: 27 December 2018} Published online: 14 February 2019

\section{References}

1. Zhang J, Li S, Li L, Li M, Guo C, Yao J, Mi S. Exosome and exosomal microRNA: trafficking, sorting, and function. Genomics Proteomics Bioinformatics. 2015:13:17-24.

2. Kozomara A, Griffiths-Jones S. miRBase: annotating high confidence microRNAs using deep sequencing data. Nucleic Acids Res. 2014:42:D68-73.

3. Maltby S, Plank M, Tay HL, Collison A, Foster PS. Targeting microRNA function in respiratory diseases: mini-review. Front Physiol. 2016;7:21.

4. Głobińska A, Pawełczyk M, Kowalski ML. MicroRNAs and the immune response to respiratory virus infections. Expert Rev Clin Immunol. 2014;10: 963-71

5. El Kholy A, Mostafa N, Ali A, Soliman M, El-Sherbini S, Ismail R, El Basha N, Magdy R, El Rifai N, Hamed D. The use of multiplex PCR for the diagnosis of viral severe acute respiratory infection in children: a high rate of codetection during the winter season. Eur J Clin Microbiol Infect Dis. 2016;35: 1607-13.

6. Booton R, Lindsay MA. Emerging role of MicroRNAs and long noncoding RNAs in respiratory disease. CHEST J. 2014;146:193-204.

7. Brown D, Rahman M, Nana-Sinkam SP. MicroRNAs in respiratory disease. A clinician's overview. Ann Am Thorac Soc. 2014;11:1277-85.

8. Bartel DP. MicroRNAs: genomics, biogenesis, mechanism, and function. Cell. 2004:116:281-97.

9. Rupani H, Sanchez-Elsner T, Howarth P. MicroRNAs and respiratory diseases. Eur Respir J. 2013:41:695-705.

10. Tenoever BR. RNA viruses and the host microRNA machinery. Nat Rev Microbiol. 2013:11:169.

11. Kitazawa H, Villena J. Modulation of respiratoryTLR3-anti-viral response by probiotic microorganisms: lessons learned from Lactobacillus rhamnosus CRL1505; 2014.

12. Lanier LL. Evolutionary struggles between NK cells and viruses. Nat Rev Immunol. 2008;8:259-68.

13. Manjarrez-Zavala ME, Cabello-Gutiérrez C, Rosete-Olvera DP, GutiérrezGonzález LH, Ocadiz-Delgado R. Pathogenesis of viral respiratory infection. London: INTECH Open Access Publisher; 2013.

14. Gordon S. Pattern recognition receptors: doubling up for the innate immune response. Cell. 2002;111:927-30.

15. Zhang Y, Li Y. Regulation of innate receptor pathways by microRNAs. Sci China Life Sci. 2012;56:13-8.

16. Hotz C, Roetzer LC, Huber T, Sailer A, Oberson A, Treinies M, Heidegger S, Herbst T, Endres S, Bourquin C. TLR and RLR signaling are reprogrammed in opposite directions after detection of viral infection. J Immunol. 2015;195: 4387-95.

17. Gantier MP. New perspectives in MicroRNA regulation of innate immunity. J Interf Cytokine Res. 2010:30:283-9.

18. Aoshi T, Koyama S, Kobiyama K, Akira S, Ishii KJ. Innate and adaptive immune responses to viral infection and vaccination. Curr. Opin. Virol. 2011; 1:226-32.

19. Gantier MP, Sadler AJ, Williams BR. Fine-tuning of the innate immune response by microRNAs. Immunol Cell Biol. 2007:85:458-62.

20. Li Y, Shi X. MicroRNAs in the regulation of TLR and RIG-I pathways. Cell. Mol. Immunol. 2013;10:65-71.
21. Zhao L, Zhu J, Zhou H, Zhao Z, Zou Z, Liu X, Lin X, Zhang X, Deng X, Wang $R$. Identification of cellular microRNA-136 as a dual regulator of RIG-Imediated innate immunity that antagonizes H5N1 IAV replication in A549 cells. Sci Rep. 2015:5:14991.

22. O'neill LA, Sheedy FJ, McCoy CE. MicroRNAs: the fine-tuners of toll-like receptor signalling. Nat Rev Immunol. 2011;11:163-75.

23. Oglesby IK, McElvaney NG, Greene CM. MicroRNAs in inflammatory lung disease-master regulators or target practice? Respir Res. 2010;11:148.

24. Katze MG, He Y, Gale M. Viruses and interferon: a fight for supremacy. Nat Rev Immunol. 2002;2:675-87.

25. Sedger LM. microRNA control of interferons and interferon induced antiviral activity. Mol Immunol. 2013;56:781-93.

26. Forster SC, Tate MD, Hertzog PJ. MicroRNA as type I interferon-regulated transcripts and modulators of the innate immune response. Front Immunol. 2015;6:334.

27. Johnston SL, Pattemore PK, Sanderson G, Smith S, Campbell MJ, Josephs LK Cunningham A, Robinson BS, Myint SH, Ward ME. The relationship between upper respiratory infections and hospital admissions for asthma: a timetrend analysis. Am J Respir Crit Care Med. 1996:154:654-60.

28. Renwick N, Schweiger B, Kapoor V, Liu Z, Villari J, Bullmann R, Miething R, Briese T, Lipkin Wl. A recently identified rhinovirus genotype is associated with severe respiratory-tract infection in children in Germany. J Infect Dis. 2007;196:1754-60

29. Rossmann MG, Arnold E, Erickson JW, Frankenberger EA, Griffith JP, Hecht $\mathrm{H}-\mathrm{J}$, Johnson JE, Kamer G, Luo M, Mosser AG. Structure of a human common cold virus and functional relationship to other picornaviruses. Nature. 1985;317:145

30. Calvén J, Yudina $Y$, Uller L. Rhinovirus and dsRNA induce RIG-l-like receptors and expression of interferon $\beta$ and $\lambda 1$ in human bronchial smooth muscle cells. PLoS One. 2013:8:e62718.

31. Slater L, Bartlett NW, Haas JJ, Zhu J, Walton RP, Sykes A, Dahdaleh S, Clarke DL, Belvisi MG, Kon OM. Co-ordinated role of TLR3, RIG-I and MDA5 in the innate response to rhinovirus in bronchial epithelium. PLoS Pathog. 2010;6:e1001178.

32. Dweep H, Sticht C, Gretz N. In-silico algorithms for the screening of possible microRNA binding sites and their interactions. Curr. Genomics. 2013;14:127-36.

33. Megremis S, Taka S, Oulas A, Kotoulas G, lliopoulos I, Papadopoulos NG. O20-human rhinovirus replication-dependent induction of micro-RNAs in human bronchial epithelial cells. Clin Transl Allergy. 2014:4:020.

34. Bondanese VP, Francisco-Garcia A, Bedke N, Davies DE, Sanchez-Elsner T. Identification of host miRNAs that may limit human rhinovirus replication. World J Biol Chem. 2014;5:437-56.

35. Ouda R, Onomoto K, Takahasi K, Edwards MR, Kato H, Yoneyama M, Fujita T. Retinoic acid-inducible gene l-inducible miR-23b inhibits infections by minor group rhinoviruses through down-regulation of the very low density lipoprotein receptor. J Biol Chem. 2011:286:26210-9.

36. Bossert B, Conzelmann K-K. Respiratory syncytial virus (RSV) nonstructural (NS) proteins as host range determinants: a chimeric bovine RSV with NS genes from human RSV is attenuated in interferon-competent bovine cells. Jirol. 2002:76:4287-93.

37. Collins PL, Wertz GW. Human respiratory syncytial virus genome and gene products. In: Concepts in viral pathogenesis II. New York: Springer; 1986. p. 40-6.

38. Fuentes S, Tran KC, Luthra P, Teng MN, He B. Function of the respiratory syncytial virus small hydrophobic protein. J Virol. 2007:81:8361-6.

39. Falsey AR, Hennessey PA, Formica MA, Cox C, Walsh EE. Respiratory syncytial virus infection in elderly and high-risk adults. N Engl J Med. 2005:352:1749-59.

40. Glezen WP, Taber LH, Frank AL, Kasel JA. Risk of primary infection and reinfection with respiratory syncytial virus. Am. J. Dis. Child. 1986;140:543-6.

41. Kim HW, Canchola JG, Brandt CD, Pyles G, Chanock RM, Jensen K, Parrott $\mathrm{RH}$. Respiratory syncytial virus disease in infants despite prior administration of antigenic inactivated vaccine. Am J Epidemiol. 1969:89:422-34.

42. Rossi GA, Silvestri M, Colin AA. Respiratory syncytial virus infection of airway cells: role of microRNAs. Pediatr Pulmonol. 2015:50:727-32.

43. Inchley CS, Sonerud T, Fjærli HO, Nakstad B. Nasal mucosal microRNA expression in children with respiratory syncytial virus infection. BMC Infect Dis. 2015;15:150

44. Thornburg NJ, Hayward SL, Crowe JE. Respiratory syncytial virus regulates human microRNAs by using mechanisms involving beta interferon and NFkB. MBio. 2012:3:e00220-12.

45. Bakre A, Mitchell P, Coleman JK, Jones LP, Saavedra G, Teng M, Tompkins SM, Tripp RA. Respiratory syncytial virus modifies microRNAs regulating host genes that affect virus replication. J Gen Virol. 2012;93:2346-56. 
46. Prins J, Wolthers K, Kamphuisen P, Rosendaal F, Loffeld R, van der Putten A, Janssen M, Laheij R, Jansen J, de Boer W: Human metapneumovirus: a new pathogen in children and adults 177. Medicine 2004, 2:1-6.

47. Bhella D, Ralph A, Murphy LB, Yeo RP. Significant differences in nucleocapsid morphology within the Paramyxoviridae. J Gen Virol. 2002;83:1831-9.

48. van den Hoogen BG, Bestebroer TM, Osterhaus AD, Fouchier RA. Analysis of the genomic sequence of a human metapneumovirus. Virology. 2002;295:119-32.

49. Gern JE, Rosenthal LA, Sorkness RL, Lemanske RF. Effects of viral respiratory infections on lung development and childhood asthma. J Allergy Clin Immunol. 2005;115:668-74.

50. Martinez FD. Heterogeneity of the association between lower respiratory illness in infancy and subsequent asthma. Proc Am Thorac Soc. 2005;2:157-61.

51. Williams JV, Harris PA, Tollefson SJ, Halburnt-Rush LL, Pingsterhaus JM, Edwards KM, Wright PF, Crowe JE Jr. Human metapneumovirus and lower respiratory tract disease in otherwise healthy infants and children. $\mathrm{N}$ Engl J Med. 2004;350:443-50.

52. Deng J, Ptashkin RN, Wang Q, Liu G, Zhang G, Lee I, Lee YS, Bao X. Human metapneumovirus infection induces significant changes in small noncoding RNA expression in airway epithelial cells. Mol. Ther.-Nucleic Acids. 2014;3:e163.

53. Jiang Z, Nagata N, Molina E, Bakaletz LO, Hawkins H, Patel JA. Fimbriamediated enhanced attachment of nontypeable Haemophilus influenzae to respiratory syncytial virus-infected respiratory epithelial cells. Infect Immun. 1999;67:187-92.

54. Samir M, Pessler F. Small non-coding RNAs associated with viral infectious diseases of veterinary importance: potential clinical applications. Front Vet Sci. 2016:3:22

55. Engin A. Influenza type A (H5N1) virus infection. Mikrobiyol Bul. 2007;41: 485-94.

56. Peng F, He J, Loo JFC, Yao J, Shi L, Liu C, Zhao C, Xie W, Shao Y, Kong SK. Identification of microRNAs in throat swab as the biomarkers for diagnosis of influenza. Int J Med Sci. 2016;13:77.

57. Horimoto T, Kawaoka Y. Influenza: lessons from past pandemics, warnings from current incidents. Nat Rev Microbiol. 2005;3:591-600.

58. García-García J, Ramos C. Influenza, an existing public health problem. Salud Publica Mex. 2006;48:244-67.

59. Song L, Liu H, Gao S, Jiang W, Huang W. Cellular microRNAs inhibit replication of the H1N1 influenza A virus in infected cells. J Virol. 2010;84: 8849-60.

60. Izzard L, Stambas J. Harnessing the power of miRNAs in influenza A virus research. Br J Virol. 2015:2:28

61. Ma YJ, Yang J, Fan XL, Zhao HB, Hu W, Li ZP, Yu GC, Ding XR, Wang JZ, Bo $X C$. Cellular microRNA let-7c inhibits M1 protein expression of the H1N1 influenza A virus in infected human lung epithelial cells. J Cell Mol Med. 2012;16:2539-46

62. Nakamura S, Horie M, Daidoji T, Honda T, Yasugi M, Kuno A, Komori T, Okuzaki D, Narimatsu H, Nakaya T. Influenza A virus-induced expression of a GalNAc transferase, GALNT3, via MicroRNAs is required for enhanced viral replication. J Virol. 2016;90:1788-801.

63. Berkhout B, van Hemert F. On the biased nucleotide composition of the human coronavirus RNA genome. Virus Res. 2015;202:41-7.

64. Moreno J. Actualidad científica: Síndrome Respiratorio agudo y grave. Monografías de la Fundación José Casares Gil; 2009.

65. Al-Tawfiq JA, Zumla A, Memish ZA. Coronaviruses: severe acute respiratory syndrome coronavirus and Middle East respiratory syndrome coronavirus in travelers. Curr Opin Infect Dis. 2014;27:411-7.

66. Al-Hazmi A. Challenges presented by MERS corona virus, and SARS corona virus to global health. Saudi J Biol Sci. 2016;23:507-11.

67. Trombetta H, Faggion HZ, Leotte J, Nogueira MB, Vidal LR, Raboni SM. Human coronavirus and severe acute respiratory infection in Southern Brazil. Pathog Glob Health. 2016;110:113-8.

68. Huang $\mathrm{CY}, \mathrm{Hsu}$ YL, Chiang WL, Hou MH. Elucidation of the stability and functional regions of the human coronavirus OC43 nucleocapsid protein. Protein Sci. 2009;18:2209-18.

69. Lai FW, Stephenson KB, Mahony J, Lichty BD. Human coronavirus OC43 nucleocapsid protein binds microRNA 9 and potentiates NF-KB activation. J Virol. 2014;88:54-65.

70. Stark CJ, Atreya C. Molecular advances in the cell biology of SARS-CoV and current disease prevention strategies. Virol J. 2005;2:35.

71. Qian S, J-y D, Xie R, An J-h, Ao X-j, Z-g Z, J-g S, Y-z D, Z-t C, Zhu B. MicroRNA expression profile of bronchioalveolar stem cells from mouse lung. Biochem Biophys Res Commun. 2008;377:668-73.
72. Mallick B, Ghosh Z, Chakrabarti J. MicroRNome analysis unravels the molecular basis of SARS infection in bronchoalveolar stem cells. PLoS One. 2009;4:e7837.

73. Rossbach M. Small non-coding RNAs as novel therapeutics. Curr Mol Med. 2010;10:361-8

74. Janssen HL, Reesink HW, Lawitz EJ, Zeuzem S, Rodriguez-Torres M, Patel K, van der Meer AJ, Patick AK, Chen A, Zhou Y. Treatment of HCV infection by targeting microRNA. N Engl J Med. 2013;368:1685-94.

75. Thibault PA, Wilson JA. Targeting miRNAs to treat hepatitis $C$ virus infections and liver pathology: inhibiting the virus and altering the host. Pharmacol Res. 2013;75:48-59.

76. Bouchie A. First microRNA mimic enters clinic. Nat Res. 2013:31;577-78.

77. Mobergslien A, Sioud M. Exosome-derived miRNAs and cellular miRNAs activate innate immunity. J. Innate Immun. 2014;6:105-10.

78. Li J, Arévalo MT, Diaz-Arévalo D, Chen Y, Choi J-G, Zeng M. Generation of a safe and effective live viral vaccine by virus self-attenuation using speciesspecific artificial microRNA. J Control Release. 2015;207:70-6.

79. Zhou Z, Li X, Liu J, Dong L, Chen Q, Liu J, Kong H, Zhang Q, Qi X, Hou D. Honeysuckle-encoded atypical microRNA2911 directly targets influenza A viruses. Cell Res. 2015:25:39.

80. Rosas-Taraco AG, Higgins DM, Sánchez-Campillo J, Lee EJ, Orme IM, González-Juarrero M. Intrapulmonary delivery of XCL1-targeting small interfering RNA in mice chronically infected with Mycobacterium tuberculosis. Am J Respir Cell Mol Biol. 2009:41:136-45.

81. Rosas-Taraco AG, Higgins DM, Sánchez-Campillo J, Lee EJ, Orme IM, González-Juarrero M. Local pulmonary immunotherapy with siRNA targeting TGF $\beta 1$ enhances antimicrobial capacity in Mycobacterium tuberculosis infected mice. Tuberculosis. 2011;91:98-106.

82. Qiu Y, Lam JK, Leung SW, Liang W. Delivery of RNAi therapeutics to the airways_from bench to bedside. Molecules. 2016;21:1249.

83. QIAGEN. The GeneGlobe data analysis center. 2017. https://www.qiagen com/mx/geneglobe/. Accesed 14 Mar 2017
Ready to submit your research? Choose BMC and benefit from:

- fast, convenient online submission

- thorough peer review by experienced researchers in your field

- rapid publication on acceptance

- support for research data, including large and complex data types

- gold Open Access which fosters wider collaboration and increased citations

- maximum visibility for your research: over $100 \mathrm{M}$ website views per year

At $\mathrm{BMC}$, research is always in progress.

Learn more biomedcentral.com/submissions 